\title{
The effectiveness of intensive mobilization technique combined with capsular distension for adhesive capsulitis of the shoulder
}

Sunwook Park, Hansuk Lee*

From 4th Congress of the International Foot and Ankle Biomechanics (i-FAB) Community

Busan, Korea. 8-11 April 2014

\section{Background}

The management of Adhesive Capsulitis(AC) is controversal. Both capsular distension after intraarticular injection and mobilization therapy are known as highly effective treatment of painful and limited shoulder joint. The aim of this study was to determine the synergistic effect of intensive mobilization technique combined with capsular distension for patients with adhesive capsulitis in improving shoulder ROM, pain and function.

\section{Method}

A total of 28 subjects suffering from AC were randomized into two groups. Group A received fluoroscopically guided capsular distension with steroid injection followed by intensive mobilization technique twice per week for 4 weeks and group B only received capsular distension with steroid injection.

\section{Results}

Patients were assessed using the Shoulder Pain and Disability Index (SPADI), Constant-Murley Shoulder Function Assessment Score (CS), Active Range of Motion(AROM) and Verbal Numeric Score(VNS). All measurements were obtained before injection and mobilization and 4 weeks after the procedures in order to compare with effects of the treatments.

All measured value was significantly difference in group $\mathrm{A}$ and $\mathrm{B}(\mathrm{P}<.05)$. Only external rotation ROM was not significantly difference in group $B$. The statistical differences were observed between group A and B in SPADI, CS, AROM and VNS $(\mathrm{P}<.01)$.

* Correspondence: 2gamilla@eulji.ac.kr

Department of physical therapy, Eulji University, Seongnam, Gyeonggi, Korea

\section{Conclusions}

Treatment using steroid injection with distension followed by intensive mobilization technique is recommended rather than injection treatment alone for the treatment of AC. In order to maximize the effectiveness of the two treatments further studies for optimal mobilization techniques will be needed.

Published: 8 April 2014

doi:10.1186/1757-1146-7-S1-A115

Cite this article as: Park and Lee: The effectiveness of intensive mobilization technique combined with capsular distension for adhesive capsulitis of the shoulder. Journal of Foot and Ankle Research 2014 7(Suppl 1):A115.
Submit your next manuscript to BioMed Central and take full advantage of:

- Convenient online submission

- Thorough peer review

- No space constraints or color figure charges

- Immediate publication on acceptance

- Inclusion in PubMed, CAS, Scopus and Google Scholar

- Research which is freely available for redistribution

Submit your manuscript at www.biomedcentral.com/submit
() Biomed Central 